\title{
Sabahattin Ali’nin "Hanende Melek", "Yeni Dünya" ve "Çilli” Öykülerinde Düşmüş Kadın İmgesi
}

\begin{abstract}
Alev ÖNDER*
$\ddot{O} z$

Şiir, roman gibi türlerde de eserler vermiş olan Sabahattin Ali, öykücü kimliği ön planda olan önemli bir yazardır. Eserlerinde Anadolu insanının yaşam mücadelesini yansıtırken ezen-ezilen çatışmasını sıkça ele almıştır. Öykülerinde zengin-yoksul ve şehir-köy karşıtlığını işleyen yazarın ezilen ve haksızlığa uğrayan çaresiz insanlardan yana bir tutum sergilediği görülmektedir. Sanatın toplumu iyiye ve güzele sevk etme rolüne dikkat çeken yazar, Anadolu insanının çileli yaşamını tüm çıplaklığı ile yansıtırken sınıfsal eşitsizliğin altını çizmektedir. Sabahattin Ali'nin öykülerinde toplumsal koşullar, karakterlerin söz ve davranışlarına büyük etki eder. Kadın karakterlerin ön planda olduğu "Hanende Melek" ve "Çilli" gibi öykülerde acı çeken kadın karakterler anlatılırken toplumsal konumları vurgulanır.

Çalışmamızda yazarın öykülerinde sevecen bir tavırla yaklaştığ "düşmüş" kadınların, eğlence dünyasında çalışan çilekeş kadınların anlatıldığı "Hanende Melek", "Yeni Dünya" ve "Çilli” öyküleri incelenmektedir. Esere dönük eleştiri yöntemi ile erkek yazarın kaleminde kadın karakter kurgusu değerlendirilmektedir. "Hanende Melek" ve "Çilli" öyküsünde olduğu gibi biyografik unsurlara dikkat çekilmektedir. Konya Halkevi'nde konferansta sunduğu kadın konulu metin başta olmak üzere Sabahattin Ali'nin düşüncelerini ortaya koyan yazıları çalışmamızın kaynakları arasındadır.

Öykülerde kadın imgesinin izi sürülürken kadını nesne olarak gören erkeğin toplumsal konumuna da ayna tutulmaktadır. Düşmüş kadınların onurlu ve vefalı duruşlarına dikkat çeken yazar, toplumsal gerçekleri vurgulamaktadır. Yazar, toplumcu gerçekçiliğin ilkelerini bu metinlere yansıtmış mıdır? Kadın karakterlerin kendi hemcinsleri ile ilişkilerinde bir dayanışma söz konusu mudur? Çalı̧̧mamızda bu sorulara yanıt aranmaktadır. Yazar, bencil ve duyarsız erkekler yüzünden hayatları mahvolmuş kadınların hayata tutunma çabalarına ayna tutarken erkek egemen toplumun ikiyüzlü ahlak anlayışını eleştirmektedir. Hem karakterlerin hem de toplumun yaralarına ışık tutarken dış gerçeklik ve iç gerçeklik bir arada ele alınır. Öykülerde dışlanan/horlanan/ötekileştirilen kadın karakterlerin hem bireysel hem de toplumsal kimlikleri irdelenmektedir. Çalıştıkları karanlık ve boğucu mekânların ruhu ile karakterlerin kendi ruhlarının özdeşliği dikkat çekmektedir. Öykülerin mekân kurgusunun tahlili önemlidir. Bu nedenle kadın- mekân ilişkisi de çalışmamızda önemli yer tutmaktadır.
\end{abstract}

Anahtar Kelimeler: Sabahattin Ali, düşmüş kadın imgesi, öykü.

\footnotetext{
* Dr. Öğr. Üyesi, Adana Alparslan Türkeş Bilim ve Teknoloji Üniversitesi, Adana, Türkiye.

Elmek: aonder@atu.edu.tr

https://orcid.org/0000-0003-4012-3403
}

Geliş Tarihi / Received Date: 07.07.2020

Kabul Tarihi / Accepted Date: 01.09.2020 


\title{
Fallen Woman Image In The Stories "Hanende Melek", "Yeni Dünya" and "Çilli" of Sabahattin Ali
}

\begin{abstract}
Sabahattin Ali, who wrote works such as poem and novel, is an important author who is in the forefront due to his storyteller identity. While reflecting the struggle of the Anatolian people in his works, he frequently dealt with the oppressor-oppressed conflict. It is seen that the writer who deals with rich-poor and city-village opposition in his stories takes a stand on the desperate people who are oppressed and injured. The author drawing attention to the role of art in leading society to good and beauty underlines class inequality while reflecting the harsh life of Anatolian people starkly. In Sabahattin Ali's stories, social conditions affect the words and behaviors of the characters considerably. In the stories such as "Hanende Melek" and "Çilli", where female characters are in the foreground, their social positions are emphasized while the female characters who are suffering are mentioned.

In our study, the stories such as "Hanende Melek", "Yeni Dünya" and "Çilli" where the "fallen" women whom the writer approached with a loving attitude in his stories and suffering women working in the entertainment world are told, are analyzed. The female character set-up is evaluated in the pen of the male writer with the work-oriented critique method. As in the story of "Hanende Melek" and "Çilli" in the household, attention is drawn to biographical elements. His articles revealing the thoughts of Sabahattin Ali, especially the text he presented at a conference on women at the Konya Community Center, are important sources in our study.

While tracing the image of the woman in the stories, the social position of the man who sees the woman as an object is also mirrored. Drawing attention to the honorable and loyal posture of fallen women, the author emphasizes social facts. Did the author reflect the principles of social realism to these texts? Is there solidarity in the relationship of female characters with their fellows? Answers to these questions are sought in our study. The author criticizes the hypocritical sense of decency of the male-dominated society while mirroring the efforts of women whose lives are devastated by selfish and insensitive men to hold on to life. External reality and internal reality are handled together while shedding light on the wounds of both characters and society. Both individual and social identities of female characters that are excluded / snored / marginalized are examined in the stories. The identity between the spirit of the dark and stifling spaces they work and the characters' own spirits draws attention. The analysis of the space fiction of the stories is important. For this reason, the woman-space relationship also has an important place in our study.
\end{abstract}

Keywords: Sabahattin Ali, the image of the fallen woman, story. 


\section{Extended Summary}

Sabahattin Ali, one of the most significant authors of Turkish literature, wrote in different genres such as the novel, story, poem etc. He is well-known for his story-teller identity. He describes the lives of poor people in his stories from a social realistic perspective. His works narrate the struggles of people in desperate social conditions. The author draws attention to social, political, and economic changes while reflecting the lives of oppressed and exploited people in villages and towns. In this study, the stories "Hanende Melek", "Yeni Dünya", and "Çilli" are analyzed. The author deals with fallen female characters" individual and social identities in these stories. He reveals social conditions while representing female characters who are suffering because of selfish and insensitive men. In these stories, where female characters are in the foreground, the narrator gives female figures the right to narrate their own lives. This study analyzes the writer's loving attitude towards suffering women working in the entertainment world. How were female characters' images created by the pen of this male writer? How do these stories reflect the features of social realism? What are the relations between women in the stories "Hanende Melek", "Yeni Dünya", and "Çilli"? Is there any solidarity between female figures? This study explores these questions.

Our study uses the work-oriented critique method. The images of fallen women in these stories are evaluated. Biographical elements are a notable part of the stories "Hanende Melek", "Yeni Dünya", and "Çilli". Sabahattin Ali's articles reveal his thoughts of on women's issues. We also benefited from the text he presented at a conference on women at the Konya Community Center, which is an important source for this study. The author defends women's right to education and he underlines the meaning of freedom for women in a maledominated society. We searched for the traces of this viewpoint in the stories "Hanende Melek", "Yeni Dünya", and "Çilli”.

The narrator gives important details regarding the social positions of men who see women as objects. In this study, we also examine the meaning of being 
a man in a male-dominated society. The author emphasizes that social facts play a significant role in the lives of both men and women. He does not judge fallen women. Instead, he draws attention to the honorable and loyal posture of fallen women. In our study, we indicate the examples of this attitude in the stories "Hanende Melek", "Yeni Dünya", and "Çilli". Both the individual and social identities of excluded and/or marginalized female characters are examined. We highlight the determinism that the author uses to reveal the structure of society.

The relations between women in these stories are also important. The narrator draws attention to space and objects to reflect their external and internal realities. We examine the descriptions of space in these stories. The author portrays the effects of the male dominated order on nature and women. We analyse function of the spirit of the dark spaces in these stories. We highlight the relation between the space and women in the stories "Hanende Melek", "Yeni Dünya", and "Çilli".

As Ramazan Korkmaz stated in his remarkable book "Sabahattin Ali" the author prioritized aesthetic rather than ideological concerns in his works. He is distinguished from other social realistic writers. (Korkmaz, 1997:384) While depicting poor and hopeless female characters, the narrator avoids didactic expression. In our study, we follow the influence of social realism thoroughout the stories, in which a distorted social system is exposed. Problems related to the functioning of justice in the lives of poor and hopeless women are emphasized in these stories. The author illustrates the role of insensitive society in creating these dramas. 


\section{Giriş}

Sanatın toplumu doğru ve güzele yönlendirme gücünü savunan Sabahattin Ali, eserlerinde Anadolu insanının yaşamını tüm çıplaklığı ile sergilemektedir. Yaşadığı, tanık olduğu ya da dinlediği olayları kurmaca dünyasına taşıyan yazar, karakterlerin eylemlerini şekillendiren toplumsal faktörlerin altını çizmektedir. Karakterlerin bireysel tarihinden kesitler sunarken bağlı bulundukları coğrafyanın koşullarının onların yaşamına etki gücünü ortaya koymaktadır. Toprak veya su paylaşımı kavgasında ölen, aydınlar tarafından aşağılanan, ağalar tarafından ezilen köylüleri anlatırken yetkin gözlem gücü ile dikkat çekmektedir. (Önder 2020:393). Yazar, eserlerinde toplumun sosyokültürel ve sosyoekonomik durumunun karakterlerin söz ve davranışlarını şekillendirdiğine işaret etmektedir.

Sabahattin Ali, yoksul ve çaresiz insanların dramını toplumcu gerçekçi tavırla dile getirirken propagandadan uzak durmaktadır. Sahip olduğu siyasal bilince rağmen hem toplumun hem de bireylerin psikolojisine ayna tutarken sloganlardan uzak durma çabası söz konusudur. "Öz" ve "gerçek" kavramlarını merkeze alan toplumcu gerçekçilikte yazarların siyasal bilincinin eserlerde gerçekliğin yansıtılmasına etkisi önemlidir. Ahmet Oktay, siyasal işlevi "birincil düzey” olarak gören Rus ve Sovyet kuramcılarının görüşleri doğrultusunda kaleme alınan eserlerde edebiyatın "bilinç aşılama aracı" (2003:14) olarak algılandığını vurgulamaktadır. "Toplumsal gerçeği artistik imgeler yoluyla" işleyen yazarlar, "bilen özne" olarak yansıtma edimini "dönüştürerek" gerçekleştirmekte ve "ezilen sınıflar adına" (Oktay 2003: xxvii) konuşmaktadır. Sabahattin Ali de "sınıflı" toplumda ezilen kimselerin duygu ve düşünce dünyasını karakterleri aracılığıla yansıtırken kurmacanın estetik unsurlarını ön planda tutan bir yazardır. En sert gerçeğin dahi estetize edilerek aktarıldığı eserlerinde sınıf bilinci ve sosyal ilişkiler önemli yer tutmaktadır. "Özel bir birey olan insanla toplumsal bir varlık, bir toplum üyesi olan insan arasındaki organik, çözülmez bağ”a (Oktay 2003: xvi) işaret eden Lukacs'ın vurguladığ ilişki, Sabahattin Ali'nin öykülerinin odak noktasında yer almaktadır. Yazar, kurguladığ karakterlerin bireysel ve toplumsal kimliğinin tarihsel koşulların ürünü olduğunun altını çizmektedir. 
Yoksulluk, köylülerin yol, su, sağlık ve eğitim sorunları, hapishanedeki insanların zorlu yaşamları, kötü yola düşmüş kadınların çektiği çileler, taşra-kent çatışması, toplumdan uzak bürokrat ve idarecilerin olumsuz tutumları Sabahattin Ali'nin öykülerinde sıkça ele alınan temalardır. Ressam duyarlığı ile çizdiği portrelerin inandırıcı olmasını sağlayan Sabahattin Ali, "muhayyilesinin ürettiklerini değil, reel hayatın akışı içinde yakaladığı insanların fotoğraflarını - onları kendi yataklarından kopartmadan - çeker" (Iss1 2018: 368). Görüntü ve ses unsurlar1nın atmosfer kurgusunda ustaca kullanıldığı öykülerde toplumsal yaralara parmak basılmaktadır. "Şimdiye kadar layık olduğu ehemmiyetle uğraşılmamış olan” kadın meselesi, Sabahattin Ali'ye göre "en esaslı ve derin yaralarımızdan biridir" (2020a:109). Eğitimli ve eğitimsiz kadınların yaşamlarından kesitler sunan yazar, onların bireysel ve toplumsal kimliklerini şekillendiren "iktidar" kavramına daya11 ilişki ağlarına ışık tutmaktadır.

Ataerkil toplumun sosyal örüntülerinde erkeğin "güç odağ 1 " olarak birincil konumda yer alması, kadın sorununun iyileşmeyen bir "yara” olarak kalmasında büyük role sahiptir. "Gerçek iktidardır" (Oktay 2003:71) sözü ile Foucault’un vurguladığı söylem, ataerkil değerleri yerleşik kılan unsurların inşasında önemli bir kaynaktır. Erkek egemen toplumda gündelik yaşam, eril söyleme göre şekillenmektedir. Erkek öznenin kadın bireye üstünlüğüne dayalı eşitsiz ilişkilerin içselleştirildiği toplumda ataerkil normlar yeniden üretilirken masumiyetini yitiren dil araçları, adaletsizliğin sürmesine neden olmaktadır. Bu sorunun kaynağını edebî eserler üzerinden araştıran feminist kuramcılar, kadın yazarların ve kadın karakterlerin uzun bir süre "görünmez" ya da "silik" olduğuna işaret edip edebî metinlerde erkek hegemonyasını eleştirmişlerdir.

Maggie Humm'un ifade ettiği gibi yazının sosyal kalıpları temsil etmesi, kadınların ezilmesi ya da yanlış temsilinin yazıda sergilenerek çözümlenmesi hususları hem Marksizm hem de Feminizm için önemlidir. "Marksist ve sosyalist feministler bilinci sosyal kurumların belirlediğine inanır" (2002:117). Toplumsal yapı ve değişim hem erkeğin hem de kadının günlük yaşamına şekil vermektedir. Louis Althusser'in vurguladığı gibi “ideoloji, sistemler, temsiller ve günlük hayatın ritüelleri aracıllğıyla işler” (Humm 2002:118). Toplumsal eşitsizlikleri eleştiren Sabahattin Ali'nin eserlerinde günlük hayatın her alanına sinmiş güç ilişkilerine 
ayna tutulurken sosyal kurumların işleyiş ilkeleri sorgulanmaktadır. Öykülerinde hem kapitalizmin hem de ataerkil düzenin sebep olduğu toplumsal eşitsizliklerin eleştirildiği görülmektedir. "Şu anda tüm düşünen kafaları uğraştıran ve tüm düşünceleri harekete geçiren genel sosyal sorunun yalnızca bir yanı" (Bebel 1996: 37) olarak tanımlanan kadın sorunu, Bebel'in Kadın ve Sosyalizm'de vurguladığ "toplumsal çelişkiler" ortadan kalkmadan çözülemeyecektir. Sabahattin Ali, ezilen ve küçümsenen kadın öznelerin dramını aktarırken onları çaresizliğe mahkum eden düzenin çürümüş değerlerini eleştirmektedir.

Erkek egemenliğine dayalı toplumsal düzende çıkar ilişkileri nedeni ile yaşanan yozlaşmaya ayna tutan Sabahattin Ali, "kültür gelişimimiz dolayısıyla erkek dünyası tarafından egemenlik altına alınmış ve ihmal edilmiş cins olarak" (Bebel 1996:40) kadının dünyasını önyargılardan uzak tutumla tasvir etmektedir. Onun eserlerinde kadının konumunu sadece "eş ve anne olarak belirleyen" ve "yuvayla sınırlı 'doğa mesleği’ ile" (Bebel 1996:38) tanımlayan eril söylemden uzak bir tutum söz konusudur.

Kadın bireyleri eserlerinde sadece eş ve anne rolüne mahkum etmeyen Sabahattin Ali'nin "düşmüş" kadın karakter kurgusunda sevecen bir tavır dikkat çekmektedir. "Kadın oluşu ve kadınlığı dürüst, itaatkâr, romantik, iffetli, hanımefendi ve hafifmeşrep, şeytani, yıkıcı, fettan olarak imgelenen iki sabit kümeye indirgeyen" (Öğüt 2013: 199) yazarlarda görülen ahlakçı tavırdan uzak durulduğu görülmektedir. Karakterlerin yaşam öykülerinden kesitler sunarken onları erkek egemen toplumun dayattığı kategorilere hapsetmeyen yazar, özü bakımından iki cinse de baskı uygulayan toplumsal koşulların gücünü vurgulamaktadır.

"Gramafon Avrat, Köstence Güzellik Kraliçesi, Kazlar, Hanende Melek, Yeni Dünya Çilli, Kazlar, Sıcak Su, Hasanboğuldu, İki Kadın, Mehtaplı Bir Gece” adlı öykülerinde kadın karakterler ön plandadır. (Korkmaz 1997: 190). Sınıfsal eşitsizliğin altını çizen yazar, hem kadın olarak hem de "düşmüş kadın" olarak ötekileştirilen/horlanan/ezilenlerin sıkıntılarını anlatmaktadır. Paranın egemen olduğu bir toplumda hem ekonomik koşullar hem de yerleşik ataerkil düzenden kaynaklanan eşitsizlik ve sömürü düzenine odaklanma söz konusudur. Sabahattin Ali'ye göre ikincil konuma mahkûm edilen ve ezilen kadınların bilinçlenerek kendi haklarını savunmaları gerekmektedir. Yazar, 1932'de Konya Halkevi’nde 
düzenlenen bir konferansta kadınların eğitimi ve toplumsal konumuna dair görüşlerini şu sözlerle ifade etmiştir:

“.... memleketin bütün kadınlarına medeni hayatta layık olduğu rolün verilmesi zamanı gelmiştir. Artık okuyan kızlarımızın boş fakat bilgiç ve manasız bozuk bir kukla olmaktan, alelumum kızlarımızın satılık bir mal, bir vitrin eşyas1 haline gelmekten kurtulması lazımdır. Artık köylü kadınlarımızı kara öküzün bir yardımcısı, bir yarım hayvan olmaktan kurtarmalıyız, bunun için de haricî tedbirlerden ziyade içten gelen arzular lazımdır. Kadınlarımız bunu bütün kuvvetleriyle istemeli, bunun için bütün kuvvetleriyle uğraşmalıdırlar” (Sabahattin Ali 2020a: 117).

Kadınların "vitrin eşyası" gibi algılandığı toplumu eleştiren yazar, kadınların kendi kimliklerine dair bilinçlenmeleri gerektiğini savunmaktadır. Kadın bireylerin hem cinsiyet hem de sınıf bilinci kazanmaları eşitsiz ilişkilerin son bulması hususunda önemlidir. Kendi bedenine ve ruhuna yabancılaşan kadın öznelere dayatılan toplumsal cinsiyet rolleri ataerkil düzeni sağlamlaştırmaktadır. Yüzyıllar boyunca yeniden üretilen zayıf ve edilgen kadın imgesi ile ataerkil değerler pekiştirilmektedir. Bu imgenin değişimi "bilinç yükseltme" ile mümkün olacaktır, çünkü kadın öznelerin "politik olarak ezilen bir grubun üyesi olduğunu" (Donovan 1997:165) fark etmesi gerekmektedir. Eril kodlarla örülü toplumsal ilişki ağlarına dair "farkındalık" hususunun önemine işaret eden Sabahattin Ali, edebiyatın bu noktada önemli bir rol üstlendiğini savunmaktadır: "Edebiyat, bütün sanat şekilleri ve nevileri, maddi menfaatlerden uzak ilim, hep bu dimağî hususiyetin neticeleridir. Ve ancak insan dimağına bu maddi ihtiyaçlarla alakası olmayan hissî bir faaliyet imkânını verdiğimiz zaman hayvanlıktan kurtuluruz" (Sabahattin Ali 2020a:115).

\section{Sabahattin Ali’nin Öykülerinde Düşmüş Kadın İmgesi}

"Düşmüş kadınlar Sabahattin Ali’nin öykülerinde en çok karşılaşılan kadınlardır” (Aydoğan 2014:64). Yazarın "Hanende Melek, Çilli, Yeni Dünya, Köstence Güzellik Kraliçesi, Gramofon Avrat, Mehtaplı Bir Gece" adlı öykülerinde "düşkün/hayat kadını" tasvirlerinde dışlama/aşağılama/horlama söz konusu olmaz. Şarkıcılar, kumpanya oyuncuları ve oturak âlemlerinin kadınları yarg1- 
lanmadan tasvir edilir. "Kadının bedenini satmasının temel nedeninin, sayısız kadının acı çekerek içinde yaşadığı üzücü sosyal koşullar olabileceğini” (Bebel 1996: 203) düşünen anlatıcı, kadın karakterlerin kötü yola düşüş öykülerine odaklanır. Kadınlık onurunu çiğneten kötü koşullara rağmen onların bağlı oldukları mekânlarda çalışmayı sürdürme nedenini sorgularken "çürümüş düzenin kendisini irdeler" (Tosun 2007: 91). Sınıfsal eşitsizliğin kaynağını gelir adaletsizliği ile ilişkilendiren yazar, cinsiyete dayalı eşitsizliğe samimi bir anlatımla ayna tutmaktadır. Çile çeken kadınların ekonomik bakımdan ne kadar kötü durumda oldukları belirtilirken konuya eleştirel bir tavırla yaklaşım söz konusudur. Öykülerde anlatıcı- yazar, kadın cinsini sadece biyolojik kimliği ile "ikincil" konuma hapseden erkek egemen düzenin temsilcilerini eleştirmektedir. Onların eğitimsiz, yoksul ve "düşmüş" kadına ne kadar sert davrandıklarını anlatmaktadır. Sömürü düzeni güç ilişkilerine dayalı olarak inşa edildiğinden ataerkillik ile kapitalizmin birbirini besleyerek sürdüğünün altı çizilmektedir. Yazar, ekonomik, sosyal ve kültürel bakımdan geri kalmış yerlerde zorlu hayata direnmeye çalışan kadın karakterleri kurgularken sosyolojik ve psikolojik unsurları iç içe ele almaktadır. Bu unsurların yoğun olduğu "Hanende Melek", "Yeni Dünya" ve "Çilli” adlı öykülerde kader ortağı olan çilekeş kadınların dramı, sinematografik unsurlara yer veren içten bir anlatımla dile getirilmektedir. Ataerkil toplumun sömürü düzeninin eleştirel gözle aktarıldığı bu öykülerde atmosferin canlılığı ve karakterlerin sahiciliği ön plandadır.

Sabahattin Ali'nin eserlerinde sahiciliği sağlayan önemli hususlardan biri onun yetkin gözlem gücüdür. "Türk edebiyatında Sabahattin kadar hayat hikâyesi ile eserleri iç içe geçen şair/yazar sayısı çok azdır. Yurdun çoğu yöresini - özellikle Batı Anadolu coğrafyasını - dolaşma firsatı bulan yazar, bu yörelere ilişkin gözlemlerini, izlenimlerini ve anılarını eserlerine çok canlı biçimde, estet bir anlatım ve üslupla yansıtmıştır” (Güneş, 2016:7). "Hanende Melek” öyküsünde Sabahattin Ali, Yozgat’ta gördüğü şarkıcı bir kadını anlatır. Ayşe Sıtkı İlhan'a gönderdiği 6 Temmuz 1933 tarihli mektubunda "Eğlence namına bir kahvede icra-i ahenk eden kötü bir saz heyeti vardı, bu heyetin hanendesi Melek isminde bir genç kızdı." (Sönmez 2013:320) der. "Yeni Dünya” öyküsünde “yazarla birlikte olan gözlüklü okumuş adam Muvaffak Şeref’tir. Muvaffak Şeref'in anlattığına 
göre Yeni Dünya'yı Dikmen'den Kömürcü Köyü'ne gelin götürürlerken tanımışlar" (Sönmez 2013:320). Öğretmenlik yaptığı coğrafyanın insanlarını yetkin bir gözlem gücü ile anlatan Sabahattin Ali'nin "Çilli” öyküsünde de otobiyografik unsurlar dikkat çekmektedir. Aydın'da öğretmenlik yaptığı yıllarda öğrencisi olan bir kadını sonradan İzmir'de bir barda gören yazar, onun dokunaklı öyküsünü anlatmaktadır. (Sönmez 2013:320). Üç öyküde de anlatıcının kadın karakterlere duyarlı ve merhametli yaklaşımı ön plandadır. Sorumsuz, vefasız, bencil ve duyarsız erkekler yüzünden hayatları altüst olan kadın karakterlerin maruz kaldıkları fiziksel ve psikolojik şiddet ustaca tasvir edilmektedir.

\section{Hanende Melek}

"Hanende Melek" öyküsünde bir kasaba kahvesinde üç kişiden oluşan saz heyeti ile çalışan bir kadın şarkıcının zorlu yaşam koşulları anlatılmaktadır. Yazarın "Yozgat'taki anılarından hareketle" kurguladığı öykünün "ana kişisi olan Melek'i kurgularken hiçbir değişiklik yapmamış olması yüksek ihtimaldir" (Güneş, 2016:41). Öyküde kişi ve mekân tasvirlerinde canlılık dikkat çekmektedir. İnsan- mekân ilişkisi öykünün odağında yer alan önemli hususlar arasında yer almaktadır. Öykünün girişinde dikkat çeken ayrıntılara yer verilen bir mekân tasviri söz konusudur. Saz heyeti, etekleri "eski bir kilimle örtülü kürsü k1lıklı bir kerevet”ten atlayarak inmektedir. Şarkıcı Melek inerken "eteğini tutarak ince bacaklarını aşağı uzatırdı. Bu anlar o civarda oturmuş hovarda müşteriler için mühim firsatlardı. Baygın, fakat istek dolu gözler derhal o tarafa çevrilir, tatlı bir şey yenmiş gibi posbıyıklar alt dudakla yalanırdı" (HM, s.15). Tasvirde "firsat, istek dolu gözler ve yalanma" sözcükleri kahvedeki erkek öznelerin haz arac1 olarak algıladıkları kadın bedenine bakış açılarının göstergesidir. Öyküde kadının birey kimliği ile bir bütün olarak algılanmayıp "arzu nesnesi” olarak görüldügü bir çalışma ortamı tasvir edilmektedir. Şarkı söyleyen kadının sesine değil, bedenine odaklanan müşteriler, ataerkil düzenin kadını "vitrin ögesi” olarak gören yaklaşımının temsilcileridir. Melek, sigara dumanıyla dolu ortamda, ağır bir koku eşliğinde, yarısından çoğu sarhoş olan müşterilerin sazı bastıracak kadar yükselen gürültüsüne direnerek şarkı söylemektedir. İçki yasak olmasına rağmen fincanlarına konyak dolduran müssteriler, esrar sigaralarının dumanı ile kendinden 
geçmektedir. "Gece kapladı her yeri /Keder sardı dereleri/Esmerim vay vay/ Düşman değil, sevda açtı/ Sinemdeki yâreleri." (HM, s.19) şarkısını "ağlar gibi bir ifade" ile söyleyen şarkıcının iç sıkıntısı mekânın her noktasına yayılmaktadır. Kadının etrafındaki her şeyde "zavallılık" göze çarpmaktadır. Kadın karakterin çalışma koşullarına dikkat çekilirken mekânın işlevselliği ön plandadır.

Melek, "beş seneden beri hayatını sesiyle kazanıyor, sıkıştıkça vücudunu bu sese yardımcı yapmak mecburiyetinde de kalıyordu" (HM, s.17). Kasabaya geldiği ilk günden itibaren kendisini her gece dinlemeye gelen Hüseyin Avni için takıntı hâline gelmiştir. Davavekili Hüseyin Avni, "sarhoşluğu yüzünden Hukuk Mahkemesi azalığından atılmış" çok az bir maaş ile üç çocuğu ile eşini geçindiren "çamur gibi adam" olarak tasvir edilmektedir. Kahveci: "Aksakalına da bakmaz, yazıhanesine uğrayan altmışlık köylü karılarına saldırır. Dayak yemediği gün yoktur.” (HM, s.17) sözleriyle onu eleştirmektedir. Hüseyin Avni'nin sorunlu kişiliği anlatılırken onun kadın bedenine yönelik doyumsuzluğu ve saldırganlığı vurgulanır. Yaşamında tüm değer kavramlarını yitirmiş olan Hüseyin Avni, kadınları sadece "haz nesnesi" olarak algılamaktadır. Bu bakış açısında "erotizm aşktan bağımsızdır. Kadın, geçici hazlar için bir meta olarak görülür ve değersizleştirilir” (Selvi 2018:382). Cinselliği hastalıklı bir şekilde yaşayan Hüseyin Avni’nin hedefindeki kadınlar sürekli değişmektedir. Farklı kadınlardan gelen "sakil kokular onun hurdalaşmış vücudunda 1stıraplı bir sarsıntı bırakarak yayılıyorlar, zavallıyı uykudan, hatta düşünmekten mahrum ediyorlardı" (HM, s.18). Sapkın davranışları ile dikkat çeken erkeğin doyumsuzluğu onun bilincini yitirmesine neden olmaktadır. Onun istikrarsız hâllerinin vurgulandığı öyküde cinsel doyum isteği ile nasıl saldırgan hâle geldiği anlatılmaktadır. Öyküde "vapurdumanı bir gözlük ile örtülen hastalıklı gözleri” ile tasvir edilen Hüseyin Avni, kendi derbederliğine ayna tutan "harap bir şemsiyesi”" eşliğinde korkak adımlarla yürümektedir. (HM, s.16) Şarkıcı kadını taciz eden erkeğin aslında kendi korkuları, acizliği ve sinikliği /yenikliği hususunda önemli ayrıntılar söz konusudur. Kahvedeki diğer erkekler tarafindan dışlanan Hüseyin Avni'nin yaşama dair öfkesi kadın öznelerle karşılaştı̆̆ı anda sadece cinsellik odaklı bir saldırı ile dışa vurulmaktadır. Hüseyin Avni, kahvede sadece başını saza çevirdiği anda gülümsüyor ve "uzun, seyrek dişleri, donuk pembe diş etleriyle beraber dışarı firlıyor, dudaklarının kenarından tükürükler sızıyordu” (HM, s.17). 
Öyküde erkeklik ve kadınlık hâllerinin eş zamanlı ele alındığı atmosferin canlılığı ve inandırıcılığı dikkat çekmektedir. Hüseyin Avni’ye bakarken "bu derece iğrendiği bir adama rast gelmediğini düşünen” şarkıcı kadına "asıl korkunç gelen onun yapışkan bir ifade taşıyan hareketleri ve siyah gözlüklerinin arkasında kirli bir paçavra gibi sallanan bakışlarıydı" (HM, s.17). "Bakış" ve "seyretmek" sözcükleri oldukça önemlidir. Kadın öznelerin eşya gibi algılandığı erkek egemen toplumda onların bireysel ve toplumsal kimlik inşasında yaşadıkları sorunlar, ataerkil düzenin dayattığı normlardan kaynaklanmaktadır. "Seyredilen" kadının duygu ve düşünce dünyası yok sayılarak onun sadece uzuvlarına yöneltilen "bakış" erkek iktidarının ürünüdür. Hüseyin Avni, "ihtiyar etlerini seyrek fasılalarla kamçılayan ihtiras nöbetleri" (HM, s.18) nedeni ile kendisine hâkim olamaz. "Meleğe doğru bakarken onun derhal firlayıp saldırmak isteyen vahşi bir hisse" kapıldığ belirtilir. Hüseyin Avni'nin zihninde kadın bedeninin avlanacak bir yeme dönüştüğü anlarda hayvanî tutum sergilemeye başladığına işaret edilmektedir. Melek, kahvede işi bittiğinde kendisini hana kadar götürecek garsonu "eski bir mantonun içinde vücudu titriyor gibi” (HM, s.20) beklerken Hüseyin Avni onu rahatsız eder. Genç kadının koluna yapışıp götürmeye çalışan adam onun "zayıf kolunu" sıkar. Tasvirlerde ataerkil söylemin inşa ettiği kadınlık ve erkeklik hâllerine dair ayrıntılar önemlidir. İtiş kakış sırasında davavekili, dizlerinin üstüne düşerek alnını iskemlelerden birine vurunca sesi "hırıltı gibi" çıkar. Erkeğin insanlığını yitirme anları öyküde ustaca tasvir edilmektedir. Melek "korkak gözlerle" etrafına bakar. Kadın öznenin ataerkil kodlarla örülü toplumsal kimliğe uygun zayıf ve korku dolu hâli dikkat çekmektedir. Hüseyin Avni onun bu görüntüsünden güç alarak daha da saldırganlaşmaktadır.

Öyküde eşyaların tasvirinde kadının duygu ve düşünce dünyası ile bir uyum söz konusudur. Gücü azalan kadın karakter, ayakta durmakta güçlük çekerken "tavandaki lüks lambaları parlayıp sönerek ömürlerinin azaldığını" (HM, s.21) bildirmektedir. Kadının ezildiği ve çile çektiği ortamda huzursuzluk her yere sinmektedir. Gerilimin arttığı anda Hüseyin Avni, kadın şarkıcıyı tokatlar. Bu şiddetin kaynağı "erkeklik unvanının kadını mülk sayan özelliği[dir]”(Bozoklar 2016: 69). Erkek özne, yoğun öfkesini dışavurumunun ardından kahveci ve ç1rakları tarafindan dövülerek kahvenin önüne bırakılır. Kendisinden daha güçlü 
kimseler tarafından cezalandırılan Hüseyin Avni’nin sokağa atıldığını gören kızı ona seslenir:

“-Babacığım, ne olursun babacığım, hadi gidelim!- diye ağlıyordu.

Nezleli sesi, artık biraz hafiffemiş olan yağmurun şıpırtılarına karışıyordu.

Melek yanındaki garsona:

Şu adamı kaldırıversene! dedi” (HM, s.22).

Kız çocuğunun zavallı hâlinden çok etkilenen Melek, yardımseverliği ile dikkat çeker. Babasının iki gündür eve uğramadığını, evdeki herkesin aç olduğunu anlatan çocuk, annesinin sinirlenip sürekli çocuklarını dövdüğünü dile getirir. Bu noktada anlatıcı, acı çeken bir başka kadının zorlu yaşamına ayna tutar. Melek, küçük kızdan çok etkilenir. Şarkıcı kadın, kendi çocukluğunu hatırlamış veya onu gelecekte kendisi gibi "kötü yola düşmek zorunda kalacak" bir genç kız gibi görmüş olabilir. "Yeni bir Hanende Melek adayı" (Füruzan, 2013:488) gibi görünen küçük kıza evine kadar eşlik eder. Yoksulluğun altının çizildiği öyküde zifiri karanlık sokaklarda Melek dizlerine kadar çamura battığını hisseder. Mekân tasvirleri gelir dağılımının adaletsizliğinden kaynaklanan toplumsal çelişkilere 1şık tutmaktadır. Hüseyin Avni'nin çamurlu evinde "titrek 1şıklı bir idare lambasıyla sıska bir kadın vücudu” (HM, s.23) onları üzgün ve sinirli şekilde karşılar. Melek'e bakıp "Demek şimdiki de sensin ha?” (HM, s.23) sorusunu yöneltmesi onun öfkesinin kaynağına işaret etmektedir. İki kadın bir müddet bakışırlar. Bu sahneler adeta bir film karesi gibi kurgulanır. Okur, iki rakibin karşı karşıya geldiğini düşünür. Gerilim tırmandıkça anlatıcı, sunduğu ayrıntılarla öykünün anlam dünyasının derinleşmesini sağlar. Melek çantasını açıp Hüseyin Avni’nin kendisine verdiği dört beş altın bilezikle bir çift küpeyi adamın eşine uzatır. Melek, baş1$\mathrm{n} 1$ öne eğerek konuşmaktadır. "O anda aynı erkeği paylaşamayan iki kadın değil, aynı erkek tarafından mağdur edilen iki kadın olduklarını hissederler. Bu bir dayanışma anıdır” (Esen 2013: 240). Anlatıcı, yoksulluğun mağdur ettiği kadınların ortak mağduriyetini vurgulamaktadır. Melek, evden çıkarken küçük kızın başını göğsüne bastırıp öperek kendi yevmiyesini ona verir. Anlatıcı, kadın kuşaklar1nın birbirlerine acılarını kültürel mirasın parçası gibi aktardıklarına işaret ederken feminizmin "kız kardeşlik" kavramını düşündüren bir tabloyu tasvir etmektedir. Ataerkil toplumda iktidar mekanizmalarının nasıl çalıştığına işaret edilen öykü- 
de kadınlar şiddete uğrayıp ortak acılar çekmektedir. Şarkıcı kadını tokatlayan Hüseyin Avni, yoksulluk ve aldatılmanın öfkesi ile dolu eşinin evde çocuklarını dövmesine neden olan kişidir. Erkek öznenin şiddet zincirinde temel unsur olduğuna işaret edilmektedir.

Çamurlu yollardan kendisini bekleyen han odasına geri dönüp çaresiz şekilde kötü yaşamına devam eden Melek, öyküde iyi özellikleriile anlatılmaktadır. Kadın karakterin kaderi gibi değişmeyen çamurlu yollara mahkûmiyeti gerçekçi bir yaklaşımla ele alınmaktadır. Bu noktada toplumcu gerçekçiliğin önemli üç imgesi olan "kurban, suçlu ve kurtarıcı" (Oktay 2003:3) arasındaki bağlara dikkat çekilmektedir. Güç ilişkilerinde paranın etkisini vurgulayan anlatıcı, cinsiyetler arası egemenlik ilişkilerinde eril kodların altını çizmektedir. Ezilenden yana tutum sergilerken yazarın sözcüsü konumundadır. Kadın figür, hem kapitalizmin hem de ataerkilliğin "kurban"ı olarak karşımıza çıkmaktadır. Sermaye sahibi kimselerin çıkar ilişkileri üzerine kurulan sömürü düzeni, farklı iktidar aygıtları ile beslenmektedir. Bu toplumsal dinamiklerin eleştirildiği öyküde kurban ve suçluya işaret edilse de bir kahramanın "kurtarıı”" olup kadın karakterin yaşamını aniden değiştirmesi söz konusu olmaz. Şarkıcı Melek, zorlu gündelik hayatına dönmek zorundadır. Yazar, gerçekçi bir tutumla kurguladığ 1 bu son ile bireylerin tek tek kurtuluşu yerine toplumsal düzenin insanı ezen tüm unsurlarından kurtuluş umudunun önemini vurgulamaktadır.

\section{Yeni Dünya}

"Yeni Dünya" öyküsünde oturak âlemlerine katılan, dügünlere gidip dans eden ve eski şöhretini yitirip gözden düşmüş bir kadının ölüme sürüklenişi anlatılmaktadır. "Yeni Dünya'nın hâline, düştüğü duruma acıdığını açıktan hissettiren yazarın hikâyeyi ezilen/horlanan bir kadına karşı merhamet duygularını ifade etmek, okuyucuya da yansıtmak için yazmış olması olasıdır" (Güneş 2016:98). "Hanende Melek” öyküsünde olduğu gibi "Yeni Dünya” öyküsünde de acı çeken kadın özneden yana tutumunu açık bir şekilde ortaya koyan anlatıcı, geri kalmışlı̆ğ ile dikkat çeken köy ve yoksul köylünün sorunlarına 1şık tutmaktadır. Öyküde kurban konumundaki figür sadece Yeni Dünya değildir. Onun trajik öyküsü anlatılmadan önce köyde bir dügün evinin damında "öbek öbek olmuş 
konuşan, kucağındaki yahut yanındaki bebeklerle uğraşan, onları emziren, aşağıda davulcuların etrafinda itişen çocuklara bağıran" (YD., s.79) kadınlara dikkat çekilmektedir. Kadınların sadece kadın grupları içerisinde rahat hareket ettikleri vurgulanmaktadır. Kadına sadece "kutsal annelik" rolü çerçevesinde önem veren, onun "çocuk doğurmak ve bakımını üstlenmek" ile yükümlü olduğunu savunan erkek egemen düzene eleştiri söz konusudur.

Yeni Dünya, düğün evindeki diğer kadınlardan uzakta, küçük bir odada erkeklere dans gösterisi yapmak üzere oraya getirilmiştir. Kapıdan başka hiçbir yerden 1şık almayan, toprak tabanlı odanın boğucu atmosferi ayrıntılarıyla tasvir edilmektedir. Müzik başladığında “yarı karanlığa gömülmüş” Yeni Dünya, kaşıklarını avucuna yerleştirerek daracık yerde oynamaya başlar. Dar mekâna yapılan vurgular, kadın öznenin artan iç sıkıntısı ve üzerinde hissettiği baskı ile iç içedir. İşlevsel olan mekân tasviri ile kadın karakteri boğan atmosferin onda yarattığı "sıkışmışlık" duygusu vurgulanmaktadır. "Etrafındakilere küfretmeye hazırlanır gibi suratını buruşturup kaşlarını çatarak iki yanına döner gibi” hareket eden kadının hırçın tavırları eğlenmeye gelen erkeklerin tepkisini çekmektedir. "Ülen bu kötü avradı nereden buldunuz? Dügününüze yakıştıramadım” (YD, s.80) diyen ağa başta olmak üzere odadaki erkekler dansını beğenmedikleri kadını ezmeye ve horlamaya başlarlar. Seyirlik nesne olarak algılanan kadına yönelik eleştirilerde onun çirkin, yaşlı ve yeteneksiz olduğu belirtilmektedir. Kadın bireyi güzel ve bakımlı olmaya zorlayan, onu eşya gibi algılayan ve kullanıp atan sisteme yönelik eleştiri söz konusudur. "Baksana ülen Hüseyin, marazın biri...” (YD, s.80) diye bağıran erkeklere kulak veren Yeni Dünya, "Neyim varmış ki?.. Oyna dersiniz oynarım... daha ne istersiniz ki?.. Bana buralarda ünlü Yeni Dünya derler" (YD, s.80) diye cevap verse de onu dinleyen olmaz. Kadın karakterin cevabı, eğlence dünyasında sadece erkek öznelerin arzularını yerine getirmekle yükümlü olduklarına inanan kadınların iç dünyasına ayna tutmaktadır. Kadın, eril söylemin dayattığı eşitsiz ilişkiyi içselleştirmiştir. Ataerkil düzende ezilen ve horlanan kadın özne, kendi kimliğini tanımaz ve benliğine yabancılaşır. Özbenini eril söylemin kurguladığı toplumsal değerler ışığında görmeye başlar.

Öyküde Yeni Dünya'yı beğenmeyen ve onunla birlikte dans etmesi için Deli Emine'nin getirilmesini emreden Yakup Ağa, kadınları bir yerden bir yere ta- 
şınan, her an bakımlı ve ilgi çekici olması gereken "eşya” olarak görmektedir. Yakup Ağa, ataerkil ve para odaklı sömürü düzeninin temsilcileri arasındadır. Köyde itibarının çok büyük olduğu belirtilen ağanın tasviri ezen-ezilen karşıtlığına işaret etmesi ve sınıf kavramını vurgulaması bakımından önemlidir. Anlatıcı, köyden şehre inen herkesin onun hanında kaldığını, ekinini satarken onun aracılığından faydalandığını, sıkışınca ondan para aldığını ve hükümette işi olanın veya herhangi bir olay nedeni ile mahkemeye düşenin ondan medet umduğunu söyler. $\mathrm{Bu}$ ilişki ağ 1 , sermaye sahibi kimselerin ataerkil ve kapitalist toplumda gücünü ortaya koymaktadır. Yazar, egemen sınıfların temsilcilerini var eden sistemin nasıl yerleşik k1lındığını vurgulamaktadır. "Bir kötü avrat için” (YD, s.81) Yakup Ağa'nın hatırının kırılamayacağını düşünenler, yoksul erkek köylülerdir. Yoksul köylüler de ezilen kadınlar gibi ağaların kurduğu düzende çileli bir hayat sürmektedir. İçselleştirilmiş çaresizlik söz konusudur. Köyün "itaatkâr ve edilgen” kadınları eril söylemin inşa ettiği toplumda hem ekonomik sınıf hem de cinsiyet bakımından baskı altındadır.

Öyküde hem kamusal alan hem de özel alanda baskı altında olan kadınların erkek özneye bağımlı olduklarının altı çizilmektedir. "Kadının toplumsal statüsü ve özellikleri doğa vergisi sayılarak insan soyunun kafasına içselleştirilmiştir. Böylece ataerkil ideoloji doğallık kılıfi ile meşrulaştırılmıştır" (Bozoklar 2016:53). Anlatıc1, öyküde ezen-ezilen çelişkisine dayalı sistemi doğal kılan ve onu sağlamlaştıran sosyal ilişkilere ayna tutmaktadır. Yeni Dünya gibi eğlence dünyasında çalışan kadın öznelerin üzerindeki baskının iş koşulları nedeni ile diğer kadınlardan daha fazla olduğuna işaret etmektedir.

Oturak âleminde erkek öznelere zevkli anlar yaşatmakla görevli kadınlar “daima ezilmiş ikinci sınıf insan sayılmıştır” (Bozoklar 2016:71). Bu aşağılanma ve ezilme duygusu, kadın karakterlerin yaşamında bedensel ve ruhsal tahribata neden olur. Öyküde üç beş yıl önce "ortaya çıkıp gençliği sayesinde biraz nam kazanmış” olduğu belirtilen Yeni Dünya, fiziksel ve ruhsal çöküntü yaşamaktadır. Onun bedeninde yaşanan olumsuz değişimi ayrıntılı şekilde dile getiren anlatıcı, kadının yaşam mücadelesine ışık tutmaktadır. Yeni Dünya'nın kendi cümlelerine yer veren anlatıc1, "Deli Emine gelip de ne olacak? Bir düğüne bir avrat yetmez mi?" diye konuşup onun öfkesini dışa vurmasını sağlamaktadır. "Sen de kendini 
avrat mı sayıyon?” (YD s.81) diyerek onunla çatışan erkekler ataerkil düzenin yerleşik değerlerinin temsilcileridir.

Yeni Dünya, düğün evinde kendisini aşağılayan ve ezen erkeklerle tartışırken “şehirli efendiler” bu konuşmaları çok eğlenceli bulup gülerler. Anlatıcı, halktan kopuk aydın grubu ezilen sınıflara yaklaşımları bakımından eleştirmektedir. Önemli bir toplumsal soruna dikkat çekilen öyküde "köylü, kentli, zengin, yoksul, aydın, halk arasında uçurumlar" (Karaca 1993:224) bulunmaması gerektiği vurgulanmaktadır. Köye uzun bir seyahate çıkar gibi çizme, spor kasket ve siyah gözlükle geldikleri vurgulanan "efendiler", yanlarında "yerli bir hükümdar gibi yürüyen” Yakup Ağa’ya “ecnebi seyyahlar gibi” sorular sormaktadır. Yozlaşmış düzende sermaye sahipleri kadar suçlu görülen aydın gruba da eleştirel bir bakış söz konusudur. Paranın egemen olduğu toplumsal yaşamda aydınlar, köylerin nasıl medenileşeceğine dair tartışmaya başlasa da "on dakikadan fazla bu mevzuda duramayan" (YD, s.82) kimselerdir. Köye ve köylüye yabancı olan aydınlar, çamur yığınına dönüşmüş köyde pis kokulardan rahatsız olurlar. Çamur, "Hanende Melek" öyküsünde olduğu gibi insanın insanı sömürdüğü, adaletsiz ve kirli dünyanın önemli bir sembolüdür. Yeni Dünya başta olmak üzere çileli bir yaşam süren tüm karakterler bu çamura mahkûm edilmiş kimselerdir.

Çürümüş değerleri ile eleştirilen toplumsal düzenin erkek egemen söylemi pekiştiren farklı unsurları öyküde irdelenmektedir. Ataerkil düzende genç, güzel ve sağlıklı kadını "eğlence aracı” olarak görüp onaylayan eril söylemin eleştirisi bu bakımdan önemlidir. Eril zihniyeti merkeze alan iktidar aygıtlarının gündelik yaşamın belirleyicisi olduğuna işaret edilmektedir. Yeni Dünya'nın kendisine rakip olarak köy evine getirilen Deli Emine ile diyaloğu kadın öznenin hemcinsleri ile ilişkisinin de aynı iktidar aygıtları tarafından inşa edildiğini göstermektedir. "Altı yamalı ipek çorap giyen, boyalı ve dağınık saçları, sapsarı dişleri ile kötü görünen” (YD, s.81) Yeni Dünya'nın “ifadesiz birer nokta gibi duran siyah ve biraz kanlı gözleri”ne yapılan vurgu dikkat çekicidir. Erkekler kadın özneyi "seyirlik nesne" olarak görüp şehvetle bakarken öksürük krizine rağmen dansa mecbur bırakılan kadın karakter etrafını görmemeye başlamıştır. İfadesiz kalan kadın öznenin kimliği ataerkil düzende parçalı görülmektedir. Kadın özneyi tüm birey/ insan olarak görmeyen eril söylem nedeni ile onun kendi kimliğine yabancılaş- 
ması söz konusudur. Pek çevik olduğu söylenen Deli Emine'nin karşısında tüm gücünü ortaya koyarak ayakta kalmaya çalışan Yeni Dünya'nın ölüm anına kadar sergilediği direnç, öyküde ayrıntıları ile anlatılmaktadır. Başından örtüsünü atıp saçlarını savurduğu söylenen Deli Emine, elbisesini kaldırıp "etli ve esmer butlarından dört beş parmak boyunda bir kısmı meydanda bırakmasını" (YD, s.83) sağlayarak erkek öznelerin “arzu nesnesi”ne dönüşmektedir.

Deli Emine de Yeni Dünya gibi "kurban" konumundaki kadınlar arasındadır, fakat bunun farkında değildir. Yeni Dünya'ya "Ne oturup duruyorsun?" (YD, s.83) diye kızan Deli Emine'nin kendi eşiti ile ilişkisinin dile getirilmesi önemlidir. Kadın öznelerin kendi bireysel ve toplumsal kimliğine yabanc1laşmasına neden olan ataerkil sistemde hizmet aracına dönüşme serüvenlerine ayna tutulmaktadır. Yeni Dünya, kadını "tatmin aracı" olarak gören erkeklerin ardından hemcinsi tarafından da küçümsenir ve ezilir. Kendi "aşağı konumunu doğal bir şey olarak” (Bebel 1996: 45) benimsemiş Deli Emine, günü kurtarma telaşı ile hareket etmektedir. Anlatıcı, sadece erkek öznelerin acımasız dünyasına ışık tutmaz, kadınların hem cinslerine dair tutumlarına da eleştirel yaklaşılması gerektiğine işaret eder. Erkek hegemonyasına dikkat çeken anlatıcı, ataerkil değerlerin nasıl korunduğunu ortaya koymaktadır. Sabahattin Ali’ye göre "Zavallı kızlar, ebeveynlerinin ve muhitlerinin telkini ile kendilerini satılan bir mal telakki etmeye alışmışlardır" (Sabahattin Ali 2020a:114). "Mal” gibi alg1lanan kadın karakterler kendilerine dayatılan normlara uymak zorunda kalırlar.

"Yeni Dünya” öyküsünde kadın öznenin nesne olarak algılandığı çalışma ortamının zor koşulları karşısında direniş serüveni anlatılmaktadır. Yeni Dünya'nın "senelerden beri savaştığı meydanı bu kadar kolay bırakıp çekilmek istemediği belliydi” (YD, s.84) sözü ile onun yaşam mücadelesi vurgulanmaktadır. Kadın karakterler için yaşam serüveni savaş ile eş değer hâle gelmiştir. Düğün evinde iki kadın rakibin dansını izlerken “Avratlar kızıştı ha!” (YD, s.84) diyerek birbirlerini dürten erkekler, daha rahat oturmak için yanlarındakileri itelemektedir. Yeni Dünya hasta olmasına rağmen işini kaybetmemek adına büyük çaba sarf ederek yaşam savaşını sürdürmektedir. Kenarda oturan ve tebessüm eden köylülerin ruhlarının "kütleşmiş" olduğuna işaret eden anlatıcı, onların duyarsızlı̆̆ını eleştirmektedir. His, öykünün önemli kavramlarındandır. Anlatı- 
c1, hislerini yitiren bireylerden oluşan toplumdaki bozulmaya ve çürümeye dikkat çekmektedir. Kendi yaşam koşullarına yabancılaşmış bireyler yozlaşmanın farkına varamazlar. Öyküde tasvir edilen atmosferde "Kendisini seyredenleri unutmuş gibi” (YD, s.85) sadece oynamayı sürdüren Yeni Dünya'nın uzuvları hareket etse dahi bedensel ve ruhsal bakımdan giderek kötüleştiği anlatılmaktadır. Onu seyredenler insani değerlerini yitirdikleri için kadın karakterin değişimini görmezler. Bu noktada anlatıcı kadının da erkeğin de yitirdiği öz değerlere ayna tutmaktadır.

Öykünün son bölümünde düğün sahipleri gelini almak üzere başka bir köye giderken Yeni Dünya ve Deli Emine de işleri gereğince düğün kafilesine katılırlar. İncecik entarisinin üstüne geçirdiği hazır yün hırkanın içinde titrer gibi durduğu görülen Yeni Dünya adeta yaşayan ölüye dönüşmüştür. Anlatıcı, "Hanende Melek" öyküsünde olduğu gibi kadın karakterlerin zavallı hâllerine odaklanmaktadır. Çevik ve genç olsa da Deli Emine de yüzünü dahi yıkamadan, uykusuz hâlde yola çıkmıştır. Günü kurtarma çabasını sürdüren ve kendi eşitine kötü davranan Deli Emine'nin aslında katlanmaya çalıştıkları kötü yaşam koşulları bakımından Yeni Dünya ile ortak noktada buluştuğu görülmektedir. Nefes almakta güçlük çeken Yeni Dünya, "ben o kadar yola dayanamam ki" dediğinde onun itirazını "duyan yahut aldırış eden" (YD, s.87) bulunmaz. Deli Emine de dahil herkes duyarsız davranır. Sadece erkeklerin söz ve davranışlarının önemsendiği ortamda eğlence aracı olan kadın öznenin varlığının yok sayıldığı görülmektedir. Kör ve sağır topluma dönük açık bir eleştiri söz konusu olur.

"Bizim zanaata giren insan iki kadeh rakı içip iki oynayıverince böyle yıkılmaz" diyerek Yeni Dünya'ya seslenen Deli Emine arabada "on beş on altı yaşlarındaki delikanlı" (YD, s.88) ile yakınlığını ilerletmektedir. Araba ilerlerken taşlı ve bozuk yolları betimleyen anlatıcı, köylerin çamuruna işaret etmektedir. "Çıplak ve çakı1lı bir sırta tırmanıyorlar, bomboş, bir tek ağaçsız, kirli ve soğuk tabiatın ortasında" (YD, s.88) ilerliyorlardı cümlesi önemlidir. Mekân-insan ilişkisine yapılan bu vurgu ile insani değerlerin öldüğü coğrafyada Yeni Dünya'nın da adım adım ölüme yaklaşma öyküsü anlatılmaktadır. Sömürü düzeni hem kadını hem de doğayı yok etmektedir. İkisi de ataerkillik ve kapitalizmin kurbanı olarak varoluş mücadelesi vermektedir. 
Öyküde düğün sahibi Hüseyin’e “Aman Hüseyin Ağa... Öldüm ben... Beni bir yere götür yatır!” (YD, s.90) diyen Yeni Dünya, öksürük krizlerinden kurtulamaz ve varoluş mücadelesinde yenik düşer. Kendisini götürüp evine b1raktıkları ihtiyar kadın, karanlık ve soğuk odacığında yaşayan çilekeş bir kimse olarak tasvir edilir. Anlatıcı, farklı yaş ve statülere sahip kadınların ortak sorunlarına dikkat çekerken yoksulluğun altını çizmektedir. Doğası gereği zayıf görülen kadın cinsi bağlı olduğu sınıf nedeni ile de ataerkil düzende dezavantajlı grubun bir üyesidir. Köydeki eğitimsiz ve yoksul kadınlar yazgıya dönüşen çileli bir hayat sürmektedir. Sınıf bilincine sahip olmayan bu kadınların öyküleri iç içe anlatılırken ortak acılar vurgulanmaktadır. İhtiyar kadın, parça parça bir yorganın altında titreyen Yeni Dünya'ya pişirdiği çorbadan ve bulgur aşından ikram etmiştir. "Anacığım anacığım” (YD, s.90) diye inleyerek can veren Yeni Dünya'nın ölüsünün dahi soruna dönüştüğü son sahnede ihtiyar kadının tavrının değişmesi önemli bir ayrıntıya işaret eder. Düğün sahipleri gelini alıp yola çıktıklarında hiç kimse Yeni Dünya'nın yokluğunu fark etmez. "Bakın şunlara... Allahtan korkmazlar. Hasta karıyı başıma sardıkları yetmedi de şimdi ölüsünü üstüme yıkıp gidiyorlar. Getirdiğiniz gibi alın götürün..!'(YD, s.92) diye bağıran ihtiyar kad1nın merhametinin yerini öfke almıştır. Anlatıcı, yoksul köylü kadınların yaşam koşulları nedeni ile sadece hayatta kalmaya çalıştıklarına işaret etmektedir. Yoksulluğun hem kadın hem de erkek özneyi tüm insani duygularından arındırıp nasıl katı hâle getirdiği vurgulanmaktadır. "Sizin köyün hıyanet olduğunu kim bilmez ki.. Dört gelin verdik de birini să̆ komadınız..." (YD, s.92) diyen ihtiyar kadın, o coğrafyada kadınların ölüm oranına dikkat çeker. Köy sadece Yeni Dünya'ya değil diğer kadınlara da mezar olmuştur. Anlatıcının kadın bireyleri öldüren sisteme dönük eleştirel bir bakışı öykü boyunca koruduğu anlaşılmaktadır.

Öykünün sonunda Yeni Dünya, gelin evinden getirtilen eski bir kilime sarılarak arabanın bir kenarına uzatılır. "Bir sürü çocuğun arasında birkaç avuç kuru otun üstünde uzanan ölünün sarsıntıyla kilimden dışarı firlayan başı tekerlekler taşlara çarptıkça arabanın yan tahtalarına vuruyor saçları kuru otlara ve samanlara karış1yordu" (YD, s.92). Öyküde kadın karakter, soğuk ve kuru tabiatla özdeşleşir. Canl1lık belirtisi olmayan kirli ve çamurlu doğa, kadın öznelerin iç dünyasına tutulan aynaya dönüşür. Hem kadının hem de doğanın ruhu tüm canlılı̆ııı yitirmiştir. 
Öyküde kişi ve mekân tasvirlerinde sınıfsal eşitsizliğe işaret eden anlatıcı, gelir dağılımındaki adaletsizliği vurgulamaktadır. Yeni Dünya son nefesine kadar işini korumak için çabalamış, yaşam savaşında yenik düşmüştür. Sarsıcı öykü sonları ile dikkat çeken Sabahattin Ali, Yeni Dünya'nın aslında hiç var olamadığını anlatmaya çalışmaktadır. Kadın öznelerin eşitsiz ilişkileri sorgulamadan, kendi benliklerini keşfetmeden, kör ve sağır bir toplumda sürdürdükleri gündelik hayat ataerkil düzene göre şekillenmiştir.

Öyküde kadın karakterleri kötü koşullarda çalışmaya zorlayan erkekler, ataerkilliğin güçlü olduğu taşrada toplumsal cinsiyet rollerine uygun çıar ilişkileri geliştirirler. Kadın bedenine aç diğer erkeklerinin zevk düşkünü olmalarından yararlanırlar. "Yeni Dünya" ve "Hanende Melek" öyküsünde bencil, çıkarcı ve duyarsız olduklarına işaret edilen işverenler için kadın karakterler ucuz iş gücüdür. Kadın çalışanların "daha az direnme gücü” (Bebel 1996: 235) nedeni ile onları zor koşullara mahkûm etme söz konusudur. Çilli öyküsünde de benzer bir atmosfer kurgulanırken kadın karakterleri "kullanan” eğlence sektöründe onların tükeniş serüveni anlatılmaktadır.

\section{Çilli}

“Çilli” öyküsünde İzmir'de pavyonda çalışan bir kadının trajik yaşam serüveni anlatılmaktadır. Biyografik unsurlarla kurgulanan (Sönmez 2013:320;Güneş 2016:81; Bezirci 1979:101) öyküde samimi bir anlatım dikkat çekmektedir. “Aydın Ortaokulu'nda Almanca öğretmenliği yapan, İzmir ve çevresini seven Sabahattin Ali'nin benzer hadiseyi yaşaması, hikâyede Çilli/Nigâr'ın adını bile değiştirmemiş olması yüksek ihtimaldir" (Güneş 2016:81). Bu bakımdan sahiciliği ile dikkat çeken öyküde Nigar/Çilli ve onun çalıştığ yer tasvir edilirken yazarın ressam duyarlığı ön plandadır. "Hanende Melek" ve "Yeni Dünya” öyküsünde olduğu gibi Çilli öyküsünde de zaman ve mekân unsurlarına dair ayrınt1lar karakter kurgusu ile bağlantılıdır. İzmir'in "yapışkan, sslak gecelerinde deniz, serinlik değil, sadece buğu hâlinde etrafa yayılan bir yosun ve pislik kokusu”(Ç, s.63) ile dolduğunu belirten anlatıcı, iç sıkıntısı ile girdiği barda kasvetli bir ortam ile karşılaşır. Barda çalışan kadınların yorgun yüz ifadeleri ve "pörsümüş" bedenlerine dikkat çekilir. "Yeni Dünya" öyküsünde olduğu gibi eğlence dünyas1- 
nın kadın bedenini nasıl tahrip ettiği vurgulanmaktadır. Ucuz işçi olarak görülen kadınlar, kötü çalışma ortamında sağlığını yitirse de duyarsızlık söz konusudur. Kadın çalışanı köle olarak gören işveren için önemli olan erkek müşterilerin memnuniyetidir. İç mekân tasvir edilirken kokuşmuş düzende kadının da erkeğin de farkında olmadan sömürüldüğü sistem mercek altına alınır.

“... birkaç genç, herhalde ellerine nasılsa biraz para geçmiş birkaç bekâr memur, iki kişiye bir bira içip, dans başlayınca kadınların bulunduğu masaya doğru koşmakla bu gece müthiş hovardalık ettiklerini sanıyorlardı" (Ç., s.64) diyen anlatıc1 yetkin gözlem gücünü yansıtan iç mekân tasviri sunmaktadır. Okuyucuyu erkeklik inşası üzerine düşündüren anlatıcı, bu grubun zavallılığına işaret etmektedir. Ataerkil toplumda erkeklere atfedilen "güç" olgusu karşısında aslında erkeğin kendisinin de ezildiği ve gerçeklikten uzak bir yaşama mecbur bırakıldığ vurgulanmaktadir.

Öykünün merkezinde yer alan Çilli'nin öyküsünü dile getirmeden farklı masaları dikkatle tasvir eden anlatıcı, erkek öznelerin söz ve davranışlarının onların kimliğine dair önemli ipuçları sunduğuna işaret etmektedir. Eğlence dünyasının "tüketim” ilişsilerinde kadın "eşya" gibi algılanmaktadır. "Daha ortalama bir masada dört beş Marmarisli gemici, süngercilikten kazandıkları para ile aldıkları motorun son seferinde ellerine geçeni, biri Rum, biri Türk iki şişman kadına üst üste bool ısmarlayarak tüketmeye uğraşıyorlardı" (Ç., s.64) diyen anlatıcının kadın karakterlerin farklı etnik kimliklere sahip olduğunu vurgulaması dikkat çeken bir husustur. Düşmüş kadınları sadece yabancılar arasından seçip onları ötekileştiren bir tutum sergilenmez. Kadınlar farklı ulusal kimliklerine rağmen ortak acılarda buluşmaktadır. Hepsi zorlu yaşam koşullarından bıkmıştır, fakat çaresizliğe mahkûmiyet duygusunu içselleştirmişlerdir. "Yeni Dünya" ve "Hanende Melek" öyküsünde olduğu gibi Çilli'de de eğlence dünyasında "ruhsuz" erkekler karşısında kadınların bezginliği vurgulanmaktadır:

“Okumuş yazmış olanla kara cahili, kibar terbiye görmüş olanla ömrünü ekmek parası ardında ve denizde harcarken terbiyeye vakti kalmamış olanı, iyi ile kötüyü aynı hale, aynı tek biçime sokan sarhoşluğun o ilerlemiş haddi, bütün erkeklerin suratında yılışık, şehvetli, ama tamamen ruhsuz bir maske hâlinde sırıtıyordu. Sarhoş olsun olmasın bütün kadınların yüzlerinde, hareketlerinde ise: 
“Aman Yarabbi, ne zaman bitecek!" diyen bir ifade vardı; ve bununla bu geceyi değil, bu hayatlarını da değil, her şeyi, ama her şeyi kastettikleri besbelli idi” (Ç., s.64).

Anlatıc1-yazar, barda erkeklerin kadınların yüzlerine bakmadığını, "sadece ellerinin dokunacağı bir çıplak et ve burunlarını dolduracak keskin bir kadın kokusu" aradıklarını belirtir. Kadınlar da erkeklerin yanında olsalar da zihinleri onlarla meşgul değildir. Eğleniyor gibi görünen herkes sahtelik ve ikiyüzlülük üzerine inşa edilmiş bir sosyal yapının parçasına dönüşmüştür. Öyküde okur şehvet sözcüğünün anlam dünyasını sorgulamaya başlar. Cinselliğin tabuya dönüştüğü erkek egemen düzende kadınların sadece doyum aracı olarak algılandığı eğlence dünyasında erkekler şehvet odaklıdır. Öyküde şefkatli olan sadece anlatıcıdır.

Öyküde kadın cinsine duyarlılıkla yaklaşan anlatıcı-yazar, öyküsünü anlatacağı Nigâr'ı tasvir etmeden önce diğer "kurban" kadınlar ve boğucu mekâna dair detaylı şekilde bilgi sunmaktadır. Kokuşmuş düzende varoluş mücadelesi veren Nigar/Çilli adlı kadın karakter, öyküsünü onun aracılığıyla kendi ağzından dile getirir. Masada tek başına oturan eski öğrencisini, Nigâr'1, "düşmüş kadın” olarak gördüğünde ona merhametli davranır. "Çok pencereli, çok aydınlık bir sınıf. Çok aydınlık yüzlü çocuklar ve orta sıraların en önünde oturan iki örgü saçlı, çilli bir küçük kız çocuğu gözlerimin önünde birdenbire canlanıverdi. Ben onlara Almanca okutuyordum” (Ç., s.66) diyen anlatıcı, öykü boyunca kadına karşı sevecenliğini korur. Karanlık ve kasvetli bir eğlenceli mekânında hatırlanan geçmiş, “aydınlık sınıf” imgesi ile önemli bir karşıtlık yaratmaktadır. Kadınların eğitimine büyük önem veren anlatıcı-yazarın zihninde canlanan anılar, kötü yola düşmüş kadın karakterin zekâsına ve yeteneğine ayna tutmaktadır:

"Eskişehirli bir tren memurunun çocuğu olan bu haşarı kız, bu yabancı kelimeleri ve kaideleri herkesten önce kavrıyor, ezberliyor, ayağa kalktığı zaman: -Ah, bunlar da bir şey mi sanki! Ben daha neler öğrenebilirim!- diyen yarı alaycı bir gülüşle insanın yüzüne bakıyordu. (..) Ateş gibi, her hareketinden hayat fişkıran bir çocuktu. Bütün bunlar kaç sene önceydi? Şöyle bir hesapladım. On dört sene olmuş. Ama onun yüzüne baktıkça artık o güçlükle kendini toparlayan sarhoş kadını değil, benim olduğu kadar bütün mektebin, hocaların ve arkadaşlarının sevgilisi olan küçük “Çilli”yi görüyordum. Sanki hiç değişmemişti” (Ç., 67). 
Öyküde Nigâr'ın kötü yola düşmesinin nedenleri kadın karakterin kendi cümleleri ile anlatılır. Anlatıc1, onu can kulağı ile dinler. Eğlence ortamında erkekler kadın özneleri zevk aracı olarak görürken bir erkek öznenin "düşmüş kadın" karşısında sergilediği duyarlı ve sevecen tutum önemlidir. On beş yaşında iken kırk beş yaşında bir erkek ile evlendirildiğini söyleyen Nigâr'ın öyküsü “çocuk gelin" sorununa işaret etmektedir. Öyküde erken yaşta zorla evlendirilen kızların kendi yaşamlarında söz hakkı olmadığının altı çizilir. Erkeğe bağımlı kadın bireye söz hakkı tanımayan ataerkil düzende mutsuz baba evinden çıkan kadınların baskıcı kocaları nedeni ile bir başka mutsuz ev hayatına mahkum oldukları anlaşı1ır. "Ne yapayım, oturacaktım herifle! Bu kadar sene de oturdum zaten. Ama adam ellisinden sonra rakıya vurdu. Başkalarının da sarhoş kocaları var diyeceksin. Ama çocukları da var. Onlarla avunuyorlar. Bizimkinde ise çocuk yapacak hal de yoktu. Üstelik bir de kıskanç!” (Ç., s.67) diyen Nigâr erkek egemen toplumda sorunlu evliliklerin kadınlar için çileye dönüşme serüvenini anlatır.

Öyküde Nigâr, hem fiziksel hem de psikolojik şiddete uğramış bir kadın karakterdir. Okuldan arkadaşı Kemal ile görüştüğü için kıskanç eşi "Benim bu memlekette namusum var, kaltak!” (Ç., s.67) diyerek onu dövmüştür. Kemal, Nigâr'ın dayak yediği anlara tanık olsa da kadını korumayıp kaçıp gitmeyi tercih etmiştir. Kemal, öyküde Nigâr'ın yaşamını alt üst eden bencil ve duyarsız erkekler arasında yer alır. Zorla evliliğine neden olan babası, kıskanç ve sarhoş kocasının ardından vefasız sevgili de Nigâr'ın yaşamında derin iz bırakmıştır. Okul arkadaşı ile görüştüğü için "bütün Aydın'a rüsva edilen” kadın karakter ataerkil toplumun ikiyüzlü ahlak anlayışı ile yargılanıp etiketlenmiştir. Toplumun ikiyüzlü namus anlayışını eleştiren Sabahattin Ali'ye göre kadınlar, içlerindeki en tabiî arzularını örterek "daha en masum yaşlarında riyakâr olmak mecburiyetinde kalırlar" (Sabahattin Ali 2020a:111). Öyküde anlatıcı tarafından Çilli diye hatırlanan Nigâr da çocukluğunu ve gençliğini özgürce yaşayamamış kadınlar arasındadır.

Nigâr'ın namusunu sorgulayan ve onu ataerkil değerlerle örülü toplumun ahlak anlayışı ile yargılayan kimseler, onu Aydın'a sığdırmazlar. Kadın özneyi “ahlaksız” diye yaftalayan toplum onu dışlamış ve İzmir'e gidip bir barda çalışmaya başlamasına neden olmuştur. "Ne olacak? Bir can değil mi? İnsan evde de yaşar, barda da yaşar" (Ç., s.68) diyen kadın karakterin zihnindeki "ev" imgesi dikkat çekmektedir. 
Ev, Nigâr için hiçbir zaman sığınılan mekân olmamıştır. Evde babası, barda mekân sahipleri başta olmak üzere onu kuşatan "güçlü" erkek özneler onun yaşamına yön vermeyi sürdürmüştür. "Her türlü baskı, ezilenin ezene ekonomik bağımlılığından" (Bebel 1996:46) kaynaklandığı için Nigâr kimi zaman kurtuluş ümidi doğsa da aynı bara her defasında geri dönmek zorunda kalmıştır. Âşık olduğu Kemal'in de onu üst üste hayal kırıklı̆ıına uğratması kadın karakterin üzüntüsünü çoğaltmıştır.

Öyküde Nigâr'ın geçim sıkıntısı nedeni ile çalışmak zorunda kaldığı bara yeniden gelen Kemal onun kötü durumunu görür ve "Ben seni burada birakmam, yürü gideceğiz, beraber yaşayacağız. Nikâh edeceğim!” (Ç. s.68) sözleri ile kadını kandırır. Bar sahibi ile hesabı keserken alacaklarının hepsini bağışlayan Nigâr, sorun yaşamadan oradan kaçıp kurtulmak için hakkını savunmadan oradan uzaklaşmaya çalışır. Okuyucu Kemal'in Nigâr'ın kurtarıcısı olup olmayacă̆ı sorusunun yanıtını merak eder. Nigar, ataerkil düzenin kurbanı olan kadın konumundadır. Hamile kaldığında Kemal ona hemen çocuğu aldırmasını söyler. Kadının bedenine müdahale söz konusu olur. Babasından izin almadan evlenemeyeceğini belirten Kemal, kendi babası başta olmak üzere aile büyüklerine karş1 mahcup olma korkusu ile doludur. Erkek hegemonyasına 1şık tutulan öyküde aslında özgür olmayan genç erkek de ataerkil düzenin yükleri altında kimliğini yitirmektedir. Korkak genç erkek karşısında aldığı kararlarla zorlu hayatı seçen ve anne olma hakkına sahip çıkan genç kadın, cesur bir tavır sergilemiştir. Erkeği üstün kılan sıfatlar üreten ataerkil sistemin dayattığı kalıplara eleştirel yaklaşım bu noktada da karşımıza çıkmaktadır. "Baktım asıl korkusu, çocuk olursa balta olurum diye. Bana namus numarası yapıyor. Bir gözümden düştü, bir gözümden düştü! Böyle budala yerine koymuyorlar mı, işte insana asıl o dokunuyor. (Ç., s.68) diyen Nigâr' 'n kararlılığı ve iradesi vurgulanmaktadır. Ezik ve sinik davranan Kemal kendi babasının gölgesi altındadır.

Öykünün sonunda Nigâr'ın eski hayatından kurtulamadığı ve barda kötü koşullarda çalışmayı sürdürdüğü anlaşılmaktadır. Katı gerçeklik bu öyküde de ön plandadır. Acı gerçeklerle sürekli yüzleşme hâli ve çaresizlik söz konusudur. Oğlu için bir bakıcı tutan Nigâr, "Süt veriyor, biz burda her akşam sarhoşuz. Sarhoş sütü çocuğa yaramazmış” (Ç., s.69) diyerek anlatıcı yazara annelik rolü ile seslenip sorunlarını paylaşır. Annelik sorumluluğu üzerine uzun uzun düşü- 
nen ve her ayrıntıyı sorgulayan kadın karakter masada konuştuğu hocasından kendisi için değil de çocuğu için yardım ister: "Ankara'da bildiğiniz çoktur. Orda bir çocuk yuvası varmış. Oraya yerleştiremez misiniz? İki yaşına gelsin, alırım. İsteseler bırakmam! Ama böyle kucak çocuğu olmaktan bir çıksın! (...) Onu ben doğurdum, ben büyüteceğim. Haberi bile olmayacak budalanın" (Ç., s.69) der.

Anlatıc1-yazar, Nigâr'ı dikkatle dinlerken kadın öznenin gözlerine odaklanmaktadır. "Çocuğundan bahseden her ananın gözündeki o biraz vahşi parıltı” (Ç., s.69) söz konusudur. Oğlunu büyütüp adam etmek için her fedakârlığı yapacağını vurgulayan kadın karakter, ataerkil düzenin toplumsal cinsiyet rollerine uygun "cefakâr" anne imgesine uygun bir dille konuşmaktadır. Nigâr, sözlerini noktaladığı anda "biraz önceki sarhoşluğu tekrar geri gelmiş gibi sallana sallana, masalara ve direklere tutunarak" (Ç., s.69) aynı yere döner. Yeni doğmuş bebek, umudun ve yaşam sevincinin simgesi olsa da eğlence dünyasında çalışan çileli kadınların anneliği söz konusu olduğunda tablonun değiştiği anlaşılır. Anlatıc1-yazar, romantik bir şekilde düşsel bir tablo çizerek kötü hayattan kurtuluş öyküsü anlatmak yerine gerçekliği soğuk ve can yakıcı hâli ile aktarmaktadır. Öyküde bebeğin geleceği belirsizdir. Umutlu ve dirençli bir kadın olarak konuşan Nigâr'ın yoksulluğu ve çaresizliği sürdükçe onun harekete geçmesinin mümkün olmadığına işaret edilmektedir. Kuşakların birbirlerine sadece geçmişi aktarmadıkları, geleceği de birlikte inşa ettikleri vurgulanmaktadır.

"Çilli” öyküsünde anlatıcı, kadın karakterin çektiği acıların kaynağının sosyoekonomik koşullar olduğuna işaret etmektedir. Akıllı ve dirençli biri olan kadın karakter özgürlüğünü elde edemediği için hayatında yeni bir sayfa açamaz. Kadının "diğer cinsin lütfuna ve merhametine bağımlı olmaması için ekonomik açıdan da bağımsız olması gerektiği” (Bebel 1996: 38) düşüncesinin altı çizilmektedir. Öyküde yazarın düşünce dünyasını yansıtan anlatıcı ile acı çeken karakterler arasında duygusal mesafenin azaldığı (Çelik 2013:280) görülmektedir. Kadın özne ile diyalog kuran anlatıcı-yazarın kadının deneyimlerini kendi sesi ile aktarmasını sağlaması bilinçli bir seçimdir. "Hanende Melek" ve "Yeni Dünya” öyküsünde olduğu gibi anlatıcı, "Çilli”de de çaresiz kalmış kadın öz- 
neleri önyargılardan uzak bir yaklaşımla tasvir etmektedir. Acı çeken kadınların kurtuluşunun toplumsal koşullarda yaşanacak dönüşüme bağlı olduğuna işaret etmektedir.

\section{Sonuç}

Sabahattin Ali, öykülerinde kadın konusunu ele alırken toplumsal ilişkilere odaklanmaktadır. Kadın karakterlerin söz ve davranışlarını para ve erkeğin gücünün egemen olduğu düzenin belirlediğini savunmaktadır. Kadın dünyasına ince bir duyarlılıkla yaklaşan yazara göre özgürleşemeyen kadınların ekonomik bağımsızlığg söz konusu olmadan çırpındıkları bataklıktan çıkmaları söz konusu olmayacaktır. Ezen- ezilen karşıtlığının anlatıldığı öykülerde kadın karakterler için yaşam bir savaşa dönüşmektedir. "Hanende Melek", "Yeni Dünya" ve "Çilli" öyküsünde kadın karakterler varoluş mücadelesi vermektedir. Yeni Dünya'nın eski bir kilime sarılmış ölüsünü taşıyan arabanın yolculuğu, okuyucuya yazarın “Kağnı” öyküsünde köyde nüfuz sahibi kimselerce öldürülen oğlunun ölüsünü kasabaya taşırken düşen yaşlı kadının zorlu yolculuğunu hatırlatmaktadır. Yoksulların ölülerine dahi saygısı olmayan, acımasız toplum, farklı öykülerde çilekeş kadın karakterlerin ortak acıları üzerinden eleştirilmektedir. Yaşı, sosyal statüsü, eğitim düzeyi değişse de kadın karakterler sömürü düzeninde egemen güçler karşısında pasif olmaya zorlanmaktadır.

Öykülerde kadın karakterlerin kurtulamadıkları sömürü düzeninde çalışmak zorunda kaldıkları mekânlar dar, boğucu ve karanlıktır. Mekânın işlevselliği dikkat çekicidir. Kadınların iç sıkıntısı büyüdükçe mekânın kasveti de artmaktadır. Bireyin ruhunun mekânın ruhu ile özdeşliği vurgulanmaktadır. Kötü atmosfer, yoksul ve çaresiz kadınların trajedisinde önemli role sahiptir. Üç öyküde de anlatıcı sinematografik unsurları ustaca kullanarak metnin inandırıcılığını artırmaktadır. Okur, boğucu atmosferin hem görüntü hem de sesler aracılığıyla bedeni ve ruhu yıpratan gücüne tanık olmaktadır. Nigâr'ı dinlerken onu bir an eski öğrencisi "Çilli” olarak algılayan anlatıcı yazarın merhametli tavrına rağmen kadın karakter, masasına dönüp kendi rolüne bürünmüştür. Çilli gibi Hanende Melek ve Yeni Dünya'nın görevi de kötü çalışma koşullarına tahammül ederek yaşam savaşı vermektir. Yeni Dünya, öyküde sadece genç, çevik ve sağlıklı kadın rakibi ile savaşmamıştır. Yaşlı ve hasta bedeni, 
acımasız iktidar aygıtlarının tümü ile savaşmış ve yenilmiştir. Erkek egemen düzen, kadın özneyi kendi normlarına göre şekillendirmekte ve bunu "doğal" kılan tüm aygıtları kullanmaktadır. Eğlence sektöründe eşya gibi kullanılıp atılan kadın karakterler, sadece haz aracı olarak var olabilmektedir.

Ataerkil toplum, varoluş mücadelesi veren kadınları, kendisinin "erkeğin tamamlayıcısı" olduğuna inandırıp edilgen ve ikinci konuma hapsederek sömürü düzenini sürekli kılmaktadır. Pasif ve uysal olmaya zorlanan kadın, kendi bireysel ve toplumsal kimliğinin inşasında etkili olamaz. Onun yaşam çizgisini toplumun her alanına sinmiş iktidar aygıtları belirler. Sabahattin Ali, özellikle köy ve kasabalarda ikiyüzlü namus ve ahlak anlayışının kadın öznelerin yaşamını nasıl alt üst ettiğini eserlerinde samimi bir anlatımla dile getirmektedir. Bencil ve duyarsız erkeklerin ölüme mahkûm ettiği kadın karakterler öykülerde var oluş mücadelesi verse de kurtuluş söz konusu olmaz. Çıkarcı ve acımasız erkeklerin davranışlarının kaynağı olan eril söylem hakimiyetini sürdürmektedir. Yazar, eril zihniyete dönük eleştiride sadece kadınlık hâllerinin değil erkeklik hâllerinin de irdelenmesi gerektiğini savunmaktadır. "Hanende Melek" öyküsünde itibarsız ve yenik Hüseyin Avni ile Çilli'de kişilik sahibi olmadığına işaret edilen Kemal karakteri erkeklik inşası üzerine yeniden düşünülmesini sağlar. Ataerkil değerler sadece kadınlara zarar vermez. Anlatıc1-yazar, baskı kavramının toplumda iki cinse de verdiği zarara dikkat çekmeyi amaçlar.

Öykülerde anlatıcı, ataerkil ve kapitalist toplumda baskıyı en yoğun şekilde hisseden gruplar arasında yer alan "düşmüş" kadın karakterlere sevecen bir tutum sergiler. Okur, Çilli'nin öyküsünü dinlerken onu Çilli'den Nigâr'a dönüştüren ezici güçleri anlatıcı yazarla birlikte sorgulamaktadır. Anlatıcı, üç öyküde de düşüşün kaynağına 1şık tutma çabasına odaklanır. Bunu yaparken ahlakçı ve buyurgan bir edadan uzak durulduğu görülmektedir. Yeni Dünya'yı ölüme sürükleyen olaylar zincirinde Deli Emine'nin gününü kurtarma telaşının da ekonomik ve sosyal faktörlere bağlı olduğu hissettirilir. Seyirlik eşyaya dönüşen kadınların sağlıklı ve genç hâllerine kıymet verdiği sanılan adaletsiz düzende kadının hiçbir zaman yerinin olmadığı vurgulanır. Kadın özneleri hasta ve yaşı hâle getirene dek kullanan ataerkil sistemin çarkları toplumsal duyarsızlıkla dönmeyi sürdürmektedir. Sabahattin Ali, öykülerinde bu gerçekliği en sert hâli ile okura sunmaktadır. 
Kendilerini dışlayan ve hor gören ataerkil düzenin çektirdiği acılara rağmen kendi olumlu özelliklerini yitirmemeye çalışan kadın karakterlerin kişilik tasviri önemlidir. Onların iyi özellikleri ile kurgulandığı, üç öyküde de vefalı ve duyarlı davranışlarının altının çizildiği görülmektedir. Hanende Melek, yoksul aileye acıyarak kendi kazancını onlara verirken dayanışmacı bir tutum sergilemektedir. Anlatıcı, onun aracıllğıyla kadın dünyasında birlik ve beraberliğin önemine işaret etmektedir. İnsani yönleri ön plana çıkarılan kadın karakterlerin duygu ve düşünce dünyasına tutulan ayna önemlidir. Yeni Dünya ölüme adım adım yaklaşırken dahi işini iyi yapma kaygısı ile hareket eder. Düğün sahibini mahcup etmeme çabası ile dikkat çeken kadın karakterin öyküde canı pahasına dans etmeye çalıştığı kareler, ekmek kavgasının katı gerçekliğini ortaya koyar.

Sabahattin Ali, üç öyküsünde de toplumsal sınıflara ve ezen-ezilen çelişkisine odaklanmaktadır. Eril söylem ve zihniyeti eleştirel bir tutumla ele almaktadır. Düşmüş kadınlar, oturak âlemlerinin ve eğlence dünyasının kadınları erkek hegemonyasının belirgin olduğu mekânlarda yoksul bir hayat sürmeye mahkûm edilmiştir. Erkekler için sadece cinsel tatmin aracına dönüşen kadın karakterler, bedenleri ile vardır. Ruhları örselenen yaralı kadınlar, erkek için haz nesnesi olmaktan kurtulamaz. Bedeni ve ruhu özgür olamayan kadının kendi yaşam koşullarını değiştirme gücünü ve cesaretini bulamayacağına işaret edilir. Üç öyküde de kadın karakterlerin "aşağı" konumunun yozlaşmış değerlerle örülü toplumsal yapının yerleşikliği ile korunduğu vurgulanır.

Sabahattin Ali, ataerkil ve kapitalist toplumda sömürü düzeninin en mağdur gruplarına odaklanmaktadır. Hanende Melek nasıl çamurlu yollardan geri dönerek kötü mekânda çalışmaya devam ediyor ise Nigâr da karanlık ve kirli mekânda kendi masasına dönmeye mecbur kalmıştır. Onları sömüren kişilerin adları değişse de zihniyetleri aynıdır. Anlatıcı kadın karakterler için bireysel çıkış yolunun olmadığını vurgulamaktadır. Bu noktada yazar, toplumun köklü bir zihniyet değişimine ihtiyaç duyduğuna işaret etmektedir. Birlik duygusu olmadan bireylerin tek tek kurtuluşunun mümkün olmadığı savunulmaktadır.

Zengin- yoksul karşıtlığını öykülerinde toplumcu gerçekçi çizgide anlatan yazarın ezilenden yana tavır aldığı görülmektedir. Öykülerinde "kadın sorunu" toplumsal bir mesele olarak işlenirken sebep-sonuç ilişkileri kuru ve didaktik bir 
anlatımdan uzak durularak sorgulanmaktadır. Tüketim, toplumsal çelişki, sınıfsal çatışma ve yabancılaşma kavramlarının anlam dünyasına büyük önem veren Sabahattin Ali, toplumu kendisi ile yüzleştirirken sanatçı kimliğini koruma çabasını sürdürür. Eserlerini bir ideolojinin sözcülüğünü görev edinerek kurgulamaz. Karakterlerin sicak hikâyelerinin sahiciliği okuru etkileyen önemli bir husustur. "Yeni Dünya", "Hanende Melek" ve "Çilli" bu bakımdan inandırıcılık etkisi yaratmaktadır.

Ezen- ezilen çelişkisinin kaynağı olan tarihsel ve toplumsal koşullar, kadınlık ve erkeklik tanımlarının belirleyicisidir. Ataerkil toplumda birincil konum atfedilen erkek öznelerin kadın meselesine duyarsızlığına ışık tutan anlatıcı yazar, incelenen üç öyküde de bencil, duyarsız, vefasız ve saldırgan erkek karakterleri eleştirmektedir. Çıkarları doğrultusunda yaşayan erkek özneler, ataerkil düzen korunduğu sürece Hanende Melek, Yeni Dünya ve Çilli'yi haz nesnesi olarak algılamayı sürdürecektir. Bu bakımdan öykülerde altı çizilen şu gerçeklik önemlidir: Kadın sorunu aynı zamanda erkek/erkeklik sorunudur. 


\section{Kaynakça}

Aydoğan, Bedri (2014), Sabahattin Ali’nin Yaşamı ve Yapıtlarına Genel Bir Bakış, Prof. Dr. Mehmet Özmen Armağan Kitabı, Adana: Çukurova Üniversitesi Basımevi, s.61-94.

Bebel, August (1996), Kadın ve Sosyalizm, çev. Saliha Nazlı Kaya, İstanbul: İnter Yay.

Bezirci, Asım (1979), Sabahattin Ali, İstanbul: Gözlem Yay.

Bozoklar, Kutsiye (2016), Sosyalizm Kadın İnsan, İstanbul: Ceylan Yay.

Çelik, Behçet (2013), Sabahattin Ali’nin Öykülerinde İnsan ve Ülke Manzaraları, Sabahattin Ali, ed. Sevengül Sönmez, Ankara: Kültür ve Turizm Bakanlığı Yay. s.269-290.

Donovan, Josephine (1997), Feminist Teori, çev. Aksu Bora, Meltem Ağduk Gevrek, Fevziye Sayılan, İstanbul: İletişim Yay.

Esen, Nüket (2013), Sabahattin Ali’nin Kadın Karakterleri, Sabahattin Ali, ed. Sevengül Sönmez, Ankara: Kültür ve Turizm Bakanlığı Yay. s.239-242.

Füruzan (2013), Hanende Melek, Sabahattin Ali, ed. Sevengül Sönmez, Ankara: Kültür ve Turizm Bakanlığı Yay. s.483-488.

Güneş, Mehmet (2016), Sabahattin Ali'nin Eserlerinin Kaynakları Roman, Hikâye ve Şiirlerinde Biyografik Unsurlar, Ankara: Hece Yay.

Humm, Maggie (2002), Feminist Edebiyat Eleştirisi, çev. Gönül Bakay, İstanbul: Say Yay.

Iss1, Ahmet Cüneyt (2018), "Sabahattin Ali'nin Hikâyeciliğinde Ses ve Fotoğraf”, Hece Susturulamayan Ses Sabahattin Ali, S.253, s.365- 371.

Karaca, Alâattin (1993), "Sabahattin Ali’nin Öykülerinde Toplumsal Konular”, Türkoloji Dergisi, C. 11, S.1, s.221-231.

Korkmaz, Ramazan (1997), Sabahattin Ali (İnsan ve Eser). İstanbul: Yap1 Kredi Yay.

Oktay, Ahmet (2003), Toplumcu Gerçekçiliğin Kaynakları, İstanbul: Everest Yay.

Öğüt, Hande (2013), “İçimizdeki Şeytan'a Feminist Eleştirel Bir Bakış”, Sabahattin Ali, ed. Sevengül Sönmez, Ankara: Kültür ve Turizm Bakanlığı Yay. s.195-219.

Önder, Alev (2020), "Sabahattin Ali'nin Kağnı ve Kanal Öykülerinde Sosyal Adalet”, RumeliDE Dil ve Edebiyat Araştırmaları Dergisi, S.19, s.387-398.

Sabahattin Ali (2019), Sirça Köşk, Bütün Eserleri, İstanbul:Yapı Kredi Yay.

Sabahattin Ali (2020a), Çakıcı'nın İlk Kurşunu, İstanbul: Yapı Kredi Yay. 26. bs.

Sabahattin Ali (2020b), Yeni Dünya, Bütün Eserleri, İstanbul:Yapı Kredi Yay. 34. bs.

Selvi, Merve Sevda (2018), "Sabahattin Ali’nin Hikâyelerinde Aşkın Halleri”, Hece Susturulamayan Ses Sabahattin Ali, S.253, s.372-384.

Sönmez, Sevengül (2013), "Sabahattin Ali’nin Eserlerinde Otobiyografik Öğeler”, Sabahattin Ali, ed. Sevengül Sönmez, Ankara: Kültür ve Turizm Bakanlığ Yay. s.316-321.

Tosun, Necip (2007), "Sabahattin Ali Öykülerinde Aşk ve Kadın Algııı”, Eşik Cini, S.8, s.91-95. 